\title{
Lymphocoele and localized lymphoedema of the penis
}

\author{
A. MCMILLAN \\ Department of Venereology, Ediburgh Royal Infirmary
}

\section{Summary}

Six patients with lymphocoele or sclerosing lymphangitis of the penis attended the Department of Venereology, Royal Infirmary, Edinburgh, during a 9-month period. Clinical details of these patients are given and the aetiology of the condition is discussed.

\section{Introduction}

Lymphocoele or sclerosing lymphangitis of the penis is a benign condition first described by Hoffmann (1923) under the title 'simulation of primary syphilis by gonorrhoeal lymphangitis (gonorrhoeal pseudochancre)'. In a later paper the same author (Hoffmann, 1938) concluded that the term 'non-venereal plastic lymphangitis of the coronal sulcus of the penis with circumscribed oedema', was more appropriate, as he had by then examined four more patients with similar lesions, but with no evidence of gonorrhoea. Von Berde (1937) referred to the condition as 'circular indurated lymphangitis'. For almost 25 years after the publication of these papers, no further cases were reported in the literature. Nickel and Plumb (1962) then described four cases, using the title 'non-venereal sclerosing lymphangitis of penis'. This terminology has been used in most subequent case reports (Shigematsu, Kuribayashi, and Minei, 1965; Boyd, 1970; Kandil and Al-Kashlan, 1970; Lassus, Niemi, Valle, and Kiistala, 1972; Greenberg and Perry, 1972; Stolz, van Kampen, and Vuzevski, 1975; Fiumara, 1975).

Only 34 cases seem to have been described in the literature, but in a 9-month period between January and September 1975, six heterosexual patients, suffering from this condition, attended the Department of Venereology, at the Royal Infirmary of Edinburgh. In view of the few reports of this condition, it was felt worthwile to publish details of these cases.

\section{Case reports}

Table I summarizes the clinical details of the six patients. The appearance of the lesion prompted each patient to

attend; even in Case 2, the presence of urethral discharge was of minor importance to the patient.

In each case there was a non-tender, cord-like swelling (Figure) with cartilaginous firmness on palpation in the coronal sulcus, parallel to the corona of the glans penis. Only in Case 3 did the swelling completely encircle the sulcus. There was no ulceration over the swelling which was confined to the coronal sulcus in each case. Preputial oedema was marked only in Case 6 . There was no clinical evidence of inguinal lymphadenitis, and the dorsal vein of the penis did not appear to be thrombosed.

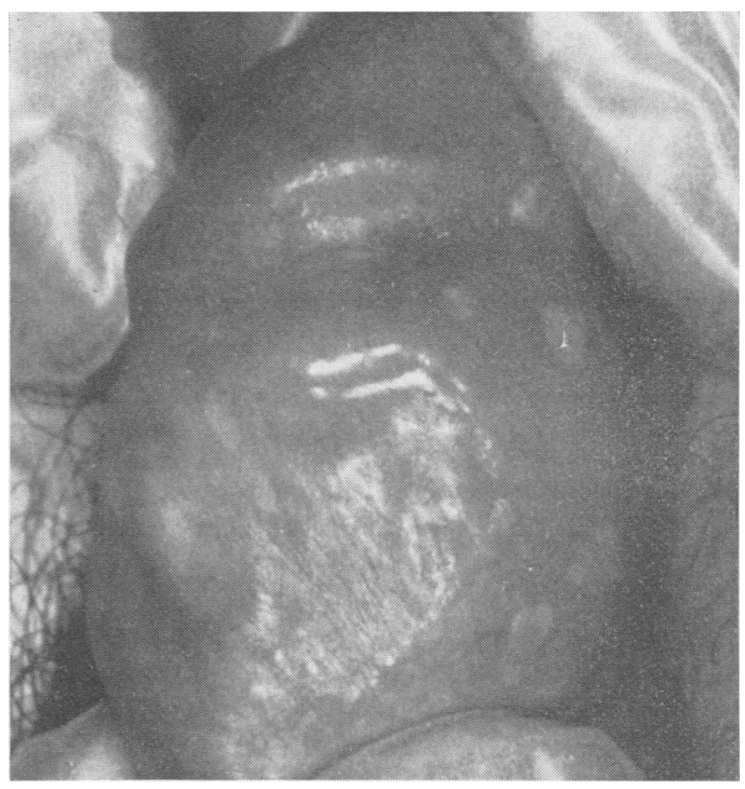

FIGURE Typical appearance of cord-like swelling

In five of the six cases, the lymphangitis was noted within 2 weeks of sexual intercourse and subsided within a further 2 weeks. The last patient (Case 6) claimed that he had not had sexual intercourse within the preceding 4 months, but this appeared to be unlikely.

In all six patients, serological tests for syphilis (Treponema pallidum haemagglutination test and Venereal Diseases Research Laboratory test) were negative at the time of presentation and 3 months later.

更

.


T A B L E I Clinical details of six patients with sclerosing lymphangitis of penis

\begin{tabular}{|c|c|c|c|c|c|c|c|c|c|c|}
\hline \multirow[b]{2}{*}{$\begin{array}{l}\text { Case } \\
\text { no. }\end{array}$} & \multirow[b]{2}{*}{$\begin{array}{l}\text { Age } \\
(y r s)\end{array}$} & \multirow[b]{2}{*}{$\begin{array}{l}\text { Marital } \\
\text { status }\end{array}$} & \multirow[b]{2}{*}{ Occupation } & \multirow[b]{2}{*}{$\begin{array}{l}\text { Past history } \\
\text { of sexually } \\
\text { transmitted diseases }\end{array}$} & \multicolumn{2}{|c|}{ Duration of lesion } & \multirow[b]{2}{*}{$\begin{array}{l}\text { Time } \\
\text { from last } \\
\text { intercourse } \\
\text { (days) }\end{array}$} & \multirow[b]{2}{*}{$\begin{array}{l}\text { Circum- } \\
\text { cised }\end{array}$} & \multirow[b]{2}{*}{$\begin{array}{l}\text { Concomitant } \\
\text { sexually } \\
\text { transmitted } \\
\text { disease }(s)\end{array}$} & \multirow[b]{2}{*}{ Comments } \\
\hline & & & & & $\begin{array}{l}\text { Before } \\
\text { attendance } \\
\text { (days) }\end{array}$ & $\begin{array}{l}\text { After } \\
\text { first } \\
\text { attendance } \\
\text { (days) }\end{array}$ & & & & \\
\hline 1 & 24 & Single & $\begin{array}{l}\text { Science } \\
\text { student }\end{array}$ & $\begin{array}{l}\text { Perianal warts } \\
6 \text { mths previously }\end{array}$ & 1 & 10 & 2 & No & None & $\begin{array}{l}\text { Developed day after } \\
\text { prolonged and frequent } \\
\text { intercourse including } \\
\text { oro-genital contact }\end{array}$ \\
\hline 2 & 19 & Single & $\begin{array}{l}\text { Electronics } \\
\text { apprentice }\end{array}$ & None & 3 & 14 & 14 & No & $\begin{array}{l}\text { Urethral } \\
\text { gonorrhoea }\end{array}$ & $\begin{array}{l}\text { Intercourse not } \\
\text { apparently frequent or } \\
\text { traumatic } \\
\text { Condition recurred after } \\
\text { intercourse } 2 \text { months } \\
\text { later, but was not } \\
\text { associated with STD on } \\
\text { this occasion. Oro-genital } \\
\text { intercourse }\end{array}$ \\
\hline 3 & 25 & Single & $\begin{array}{l}\text { Arts } \\
\text { student }\end{array}$ & None & 2 & 8 & 14 & No & $\begin{array}{l}\text { Phthirus } \\
\text { pubis }\end{array}$ & $\begin{array}{l}\text { Intercourse frequent and } \\
\text { traumatic. } \\
\text { Oro-genital contact }\end{array}$ \\
\hline 4 & 24 & Single & Art student & $\begin{array}{l}\text { Non-gonococcal } \\
\text { urethritis } 2 \text { years } \\
\text { Genital herpes } 18 \mathrm{mths}\end{array}$ & 1 & 2 & 2 & Yes & None & $\begin{array}{l}\text { Frequent sexual } \\
\text { intercourse day before } \\
\text { noticing lesion } \\
\text { Fellatio practised }\end{array}$ \\
\hline 5 & 20 & Single & $\begin{array}{l}\text { Student } \\
\text { nurse }\end{array}$ & None & 1 & 10 & 2 & No & None & $\begin{array}{l}\text { Had had similar lesion } \\
3 \text { mths previously, which } \\
\text { had lasted } 1 \text { week-no } \\
\text { medical advice sought } \\
\text { On first occasion lesion } \\
\text { followed frequent } \\
\text { intercourse, including } \\
\text { oro-genital }\end{array}$ \\
\hline 6 & 24 & Single & $\begin{array}{l}\text { Colliery } \\
\text { electrician }\end{array}$ & $\begin{array}{l}\text { Non-gonococcal } \\
\text { urethritis with } \\
\text { epididymitis } 2 \text { yrs }\end{array}$ & 1 & 18 & 4 mths & No & $\begin{array}{l}\text { Non-gonococcal } \\
\text { urethritis } \\
\text { Warts }\end{array}$ & $\begin{array}{l}\text { Alcoholic } \\
\text { Acute pancreatitis } \\
2 \text { months previously }\end{array}$ \\
\hline
\end{tabular}

Urethral gonorrhoea was diagnosed in Case 2 on the first day of attendance. To exclude gonorrhoea in the other cases, they were examined after holding their urine overnight, and urethral and prostatic secretions were examined by Gram-stained films and culture on ThayerMartin medium.

Aspiration of the swelling, using a $1 \mathrm{ml}$. tuberculin syringe and a No. 23 s.w.g. needle, was performed in Cases 2, 5, and 6. The results of examination of the fluid are shown in Table II. A total cell count was done using a white blood cell pipette and an Improved Neubauer Counting Chamber. For cytological examination a Giemsa-stained film was prepared.

Some aspirate was directly plated on to Thayer-Martin medium for isolation of Neisseria gonorrhoeae. Gramstained films were also examined and fluid was inoculated on to MacConkey agar and on blood agar plates, the latter being inoculated aerobically and anaerobically.

No fluid was obtained on attempted aspiration in Cases 1,3 , and 4.

\section{Discussion}

Although the term 'sclerosing lymphangitis' has been most commonly used to describe the condition presented, this does not correlate well with the pathology of this disorder. Excision biopsies have been performed in four cases (Nickel and Plumb, 1962; Kandil and Al-Kashlan, 1970; Lassus and others, 1972; Stolz and others, 1975), and in all cases only minimal inflammatory reaction in the form of infiltration with lymphocytes was noted. The most striking histological feature was oedematous thickening of the lymphatic vessel wall. To use the adjective 'sclerosing' is to infer permanent thickening of the wall of the affected vessel. Clinically, however, these lesions usually resolve within a month of their appearance and no vessel thickening can be detected. Perhaps the terms 'localized lymphodema' or 'lymphocoele' more appropriately describe the condition.

The appearance of the lesion in this series of patients was the same as that described by other authors. Although preputial oedema was seen in Case 6, no involvement of the dorsal lymphatic vessels of the penis, as described by Boyd (1970), was noted. Recurrence following sexual intercourse has been described (Lassus and others, 1972) and this was noted in Case 2. 
T A B L E I I Results of analysis of fluid aspirated from lymph vessel in 3 cases

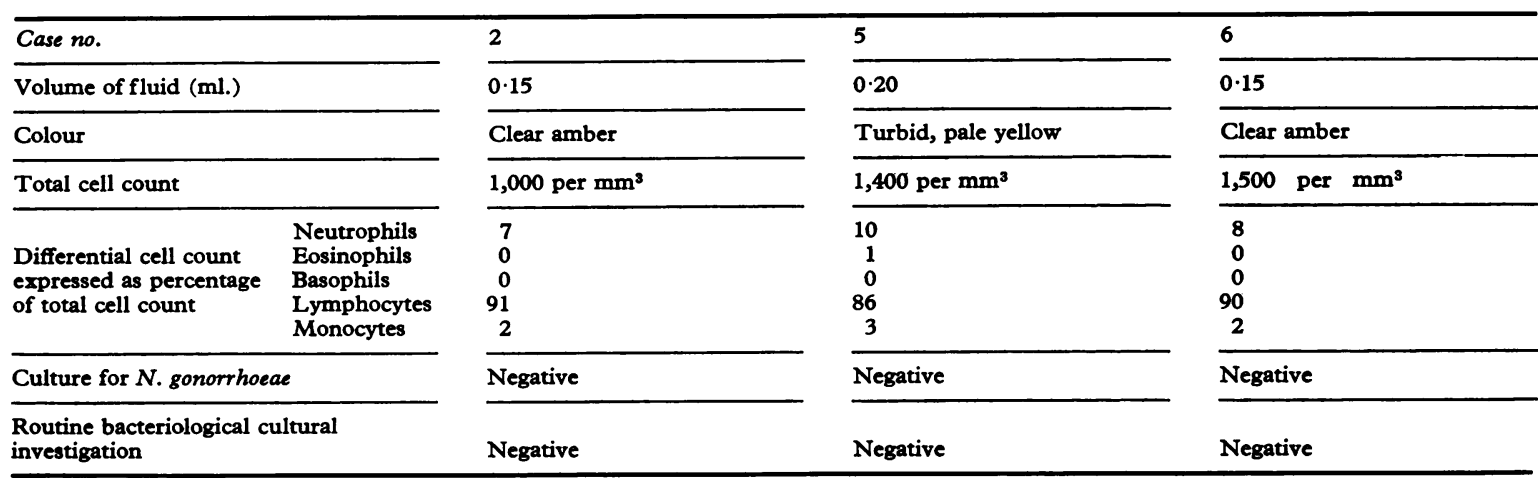

The aetiology of this disorder is obscure. Amongst factors thought to be of aetiological importance have been 'irritation by menstrual blood', 'tuberculosis', 'virus infection', and 'mechanical trauma' (Nickel and Plumb, 1962). The first two suggestions seem unlikely.

Kandil and Al-Kashlan (1970) suggested a viral aetiology, triggered by minor trauma. Viral studies, however, have not been performed in the cases reported in the literature. Patient 3 in our series had had herpesvirus Type II infection of the glans penis 18 months previously, but at the time of presentation there were no herpetic lesions, and a urethral specimen inoculated on to tissue culture cells showed no evidence of viral infection. No fluid for viral culture could be obtained from the lymphatic vessel on attempted aspiration.

Case 2 also had gonorrhoea, but fluid aspirated from the swelling did not show $N$. gonorrhoeae by Gram-staining, direct immunofluorescent staining, or culture on Thayer-Martin medium. It is quite possible that the two conditions were unrelated, but acquired at the same time. Both the original cases of sclerosing lymphangitis had urethral gonorrhoea (Hoffmann, 1923), but most subsequent cases have not been associated with this infection.

In common with a number of reported cases (Lassus and others, 1972; Stolz and others, 1975; Fiumara, 1975), the lesion appeared shortly after prolonged or frequent sexual intercourse in five of the six cases. Lassus and others (1972) considered that the disorder was a result of traumatic obstruction of a large lymph vessel, and suggested that some patients were more prone to develop obstruction through some anatomical variation of distribution or structure of the lymph vessels. Greenberg and Perry (1972) argued that, if trauma was the major precipitating factor, the prevalence of the disorder would be greater than it is. The true prevalence of the condition is, however, completely unknown. Fiumara
(1975) suggested that there might be wide variation in the severity of the condition. He described mild oedema of the prepuce, with a non-tender, cord-like swelling in the coronal sulcus, resolving within 48 hours. At the other end of the spectrum is the classical lesion described above.

(It is quite possible that physicians see only a small number of the more extreme cases.)

Occasionally, trauma, in the form of frequent, prolonged, or difficult sexual intercourse, may produce penile oedema without the appearances described above. Wilde and Canby (1973) described penile oedema in about thirty patients seen at a military hospital in Thailand; the oedema had developed some hours after traumatic intercourse and rapidly subsided.

It is interesting that five of the patients described above, and the three patients described by Fiumara (1975), had had oro-genital contact.

The lesion is self-limiting and reassurance is all that is usually required in the management of the condition.

\section{References}

BERDE, K. voN (1937) Derm. Wschr., 105, 1532

Boyd, A. S. (1970) Brit. F. Derm., 82, 632

Fiumara, N. J. (1975) Arch. Derm., 111, 902

GreEnBERG, R. D., and PERRY, T. L. (1972) Ibid., 105, 728

HOFFMANN, E. (1923) Manch. med. Wschr., 70, 1167

- (1938) Derm. Z., 78, 24

Kandil, E., and AL-Kashlan, I. M. (1970) Acta derm.venereol. (Stockh.), 50, 309

Lassus, A., Niemi, K. M., Valle, S. L., and Kirstala, U. (1972) Brit. F. vener. Dis., 48, 545

Nickel, W. R., and Plumb, R. T. (1962) Arch. Derm., 86, 761

Shigematsu, S., Kuribayashi, T., and Minei, T. (1965) Acta urol.'(Kyoto), 11, 409

Stolz, E., KAMPEN, W. J. VAN, and VuZEvSKI, V. (1975) Hautarzt, 25, 231

WiLDE, H., and CANBY, J. P. (1973) Arch. Derm., 108, 263 